\title{
Russian Newspapers on the Events of October 3-4, 1993
}

\author{
Olga Otrokova \\ Department of History \\ Bauman Moscow State Technical University \\ Moscow, Russia \\ E-mail: otrokova@yandex.ru
}

\author{
Olga Shcherbakova \\ Department of History \\ Bauman Moscow State Technical University \\ Moscow, Russia \\ E-mail: infobox900@mail.ru
}

\begin{abstract}
The subject of the study is the problem of the role of the central periodical press in the events of October 3-4, 1993. This paper reviews the problems of forming a new statehood of Russia, the study of the reaction of public and the journalistic community to the events of the "small civil war", a constitutional conflict between the President of Russia and the Supreme Council of the Russian Federation. The authors consider the role of Russian pro-government and opposition newspapers in shaping public opinion in the context of information warfare and armed conflict in early October 1993. The authors come to the conclusion that the introduction of censorship and the bet on military methods for resolving the conflict had predetermined the historic choice of new Russia consolidated the victory for the supporters of President Boris $\mathrm{N}$. Yeltsin and showed that the formation of a new civil society in Russia would be long.
\end{abstract}

Keywords-President B. N. Yeltsin; A. V. Rutskoi; R. I. Khasbulatov; mass media; newspaper; October 3-4, 1993; "twoday civil war"

\section{INTRODUCTION}

The year of 1993 was a turning point in the history of the Russian state, the time of changes in the political system, the time of determining the further development of our country. The events of the autumn 1993 received an ambiguous interpretation in the literature; nevertheless, the term "constitutional conflict of the President of Russia and the Supreme Council of the Russian Federation" should be referred to the number of established concepts. It is known that in its acute phase the constitutional conflict resulted in a "two-day civil war". The events of October, 3-4, 1993, despite their short duration, were, of course, crucial to the fate of Russia, as they contributed to the final victory of President Boris N. Yeltsin over the political opposition and led to the adoption of the modern Russian Constitution.

In August 1991, the 70-year-old Soviet stage in the history of the country was over. However, the question of forming the state structure of new Russia led to a split in the ranks of the winners, who demonstrated a different understanding of the goals of the reforms that had begun. There was no agreement either on the forms of the state system, or the presidential-parliamentary, presidential, or parliamentary republic was proposed. Economic and political difficulties were growing, which led to the collapse of President Yeltsin's coalition. Yeltsin, Vice-President A.V. Rutskoi, and. acting. Chairman of the Supreme Council R.I. Khasbulatov. All bodies and figures of the Russian government were elected in the period of the existence of the USSR and, of course, at that time were legitimate. But after dissolving the USSR, the liquidation of the Soviet Constitution, a very serious problem of power legitimacy arose. In fact, since September 1991 (known Chechen events), political confrontation is increasing.

In the context of studying our theme, it is important to mention the meeting of B.N. Yeltsin with representatives of the Russian press administration, as well as television and radio companies on August 12, 1993. The president's speech, his declared plan of resolute actions against opponents, and appeal to the media for support became the beginning of the most acute crisis in post-Soviet Russia. The peace phase ended quickly.

The transition from a peaceful period of opposition to armed confrontation began with President Boris Yeltsin's Decree No. 1400 of September 21, 1993, which contained an order to stop the activities of the Congress of People's Deputies and the Supreme Council of the Russian Federation. Soon, the Constitutional Court of the Russian Federation published a resolution e terminating the powers of President B.N. Yeltsin, which served as a catalyst for unfolding events. Since September 22, 1993 by order of B.N. Yeltsin, the building of the Supreme Council of the Russian Federation was blocked by the police and disconnected from water and electricity. Thus, the deputies appeared to be under siege.

Sources on the history of the "two-day civil war: October 3 - 4, 1993" are diverse - they are memoirs of participants in the events and acts of public authorities [1] [2] [3] [4] [5] [6] [7] [8] [9]. A significant place among them is occupied by press materials, newspaper publications. The special role of newspapers was that during the period under study, the beginning of October 1993 was that the newspapers were the operative means of delivering information to citizens, in addition to radio and television provided the Internet in Russia was just beginning.

This scope of sources has been little examined. One can mention the article by E. Markov "The Role of Mass Media 
in the Conflict of the President and the Supreme Council of Russia (1993)". The author comes to the conclusion that in the context of confrontation between the legislative and executive authorities in the Russian Federation "Mass Media ... should be the organizers of the discussion ... but ... some of them were on the side of one or another participant in the conflict, not resolving it, but, on the contrary, aggravating it" [10]. It should be noted that E.A. Markov examines the role of the media from September 21 to October 7, 1993, while beginning to study the constitutional conflict between the President of the Russian Federation and the Supreme Council much earlier, since 1992. And the most acute phase of the crisis is "a two-day civil war" fell on October 3-4, 1993.

It was the newspapers as a mirror that reflected the variety of aspects of the dramatic events taking place and fixed in fresh tracks, emotionally, but impartially the vicissitudes of constitutional conflict and civil confrontation in the Russian society. That is why the subject of scientific consideration in this article is the issue of the press reaction to the events of October 3-4, their display in the periodical press through the prism of certain views on the development prospects of the country.

\section{Highlighting EVENTS OF OCTOBER 3 - 4 IN PROGOVERNMENT AND OPPOSITION NEWSPAPERS}

The media in the period of the constitutional conflict sought to diversify the current political situation in Russia. The ideological barriers collapsed with the collapse of the USSR, pluralism and publicity became an inalienable element of the political system. In this difficult time, many new media appeared, including newspapers, which founders were those or other authorities. The events that took place were often interpreted in accordance with the political preferences of the leaders of the media. Accordingly, the completeness of the material presentation, their objectivity and the context of assessments, the formation of public opinion in the country, especially the representatives of the two opposing sides, was much depended on.

It should be noted that not always governmental authorities could influence the leaders of the media, who were formed as individuals in the years of perestroika, often being representatives of the "golden youth". Also, young graduates of the International Department of the Faculty of Journalism of the Moscow State University started forming mechanisms for influencing people's moods with the help of television and the press. Excellent starting opportunities and support from various authorities allowed them to remove the taboo on previously forbidden topics. In the fall of 1993, various publications appeared in the context of liberalism and freedom of speech. So, the point of view of the supporters of the President of the Russian Federation was reflected by "Izvestia", "Moscow News", and "Rossiyskaya Gazeta". Some newspapers opposed to the President of the Russian Federation. Part of people enjoyed authority of "Soviet Russia", "Day", "Truth", "Glasnost", "Narodnaya Pravda".
On the site of the Yeltsin Center: http://www.yeltsincenter.ru/\&hellip; which was created in 2008 to study the legacy of the first President of the Russian Federation, periodicals of the beginning of October 1993, published mainly by the newspapers - "Izvestia", "Moskovskie Novosti", "Rossiyskaya Gazeta" and "Nezavisimaya Gazeta" are publicly available. The evaluation of the tragic events of October 1993 in the state and opposition newspapers is very different: in some media of that time the term "defenders of the White House" is used, and in others - "militants" or even "terrorists".

Pro-government newspapers in every way denounced those who were on the side of the Supreme Council of the Russian Federation and "got closed in the White House", frightening the laymen with materials on the topic of what would happen to Russia if General A.V. Rutskoi came to power.

It was also thought that Boris Yeltsin would not have a peaceful choice in the circumstances. For example, the newspapers "Izvestia" and "Moscow News" of October 2 reported that among the people present in the Supreme Council building not all are the Parliament supporters [11] [12].

In the newspapers "Izvestia" and "Rossiyskaya Gazeta" in a series of articles describing the events of October 3-4, it was suggested that BN [13] [14]. Yeltsin tried to avoid the conflict to the last possible opportunity. The same point of view was expressed by the newspaper "Kommersant-Daily", trying to withstand a laconic and impartial tone. Supporters of the parliament unleashed a military conflict because they had no chance to win elections. But in a number of articles in "Izvestia" and "Rossiyskaya Gazeta" the authors in the journalistic fervor began to stick political labels, calling the defenders of the White House "fascists" [15] [16].

What the participants of the events experienced on October 3-4 is reflected in the articles of the newspaper "Izvestia". Their headlines are very eloquent: "The troops of the White House fired at a stir" (author V. Yakov); "Next to Rutskoi and Khasbulatov during the storming of the White House" (author - V. Terekhov); "The Moscow police turns out to act flawlessly" (author I. Andreev), etc. [17].

In the article "The Russian Newspaper" on October 6 it was said that most of the political parties of Russia supported B.N. Yeltsin [18]. The Free Russia Party, created by A.V. Rutskim, unequivocally condemned the actions of its leader. The article in the newspaper "Izvestia" notes that October 4 is a day of tragedy for the whole country [19]. The author called for a step towards national reconciliation.

A close look at the press review of those days shows that not a single newspaper remained indifferent to what was happening, taking the position of certain political forces. It should be noted that the publication with a great name "Nezavisimaya Gazeta" printed articles for the Day of Anger, a very ambiguous content. However, after the events of October 3-4, the editorial board made its choice and finally took a pro-government stance. 
In the fall of 1993, the opposition newspapers published irregularities that gave a different look at what was happening. In the autumn, about 13 opposition newspapers were closed, including such influential ones as «Soviet Russia» and "Pravda" [20] [21].

In a number of articles in the newspapers "Pravda" and "Soviet Russia", the authors wrote about the illegal and cynical actions of the SWAT police, whose staff, according to the authors, using the situation, was involved in the riots without protecting the peaceful people [22] [23]. In the newspaper Pravda from October 2, the author of the article compared BN [24]. Yeltsin with the dictator of the victorious democracy wrote about the danger of establishing a dictatorship.

In the articles of the newspapers "Pravda" and "Soviet Russia" of October 2, the authors noted the fact that Yeltsin's supporters tried in every possible way to stop the activities of opposition newspapers [25] [26]. In the articles of the opposition newspapers "Pravda" and "Soviet Russia" the authors protested against closing the opposition newspaper "Day" [20] [21].

Since the actions of such opposition newspapers as "Day", "Pravda", "Soviet Russia" for the period of October 3-4 and later were suspended, the political opponents of the President of the Russian Federation were deprived of the opportunity to promote their views through the press. Nevertheless, the November 1, 1993 issue of Pravda gives an idea of how the supporters of the Supreme Council withstood "two-day war". In the article "Over the Funeral Candles", the author emotionally compares the executed White House with the execution of the tsarist monarchy in 1918 [27].

\section{CONCLUSION}

The role of Russian newspapers in shaping public opinion is hard to overestimate, that is why the media is often called the "fifth power".

Thus, an analysis of the publications reporting on the events of October 3-4, 1993, issued under the impression of just-occurred incidents, shows that the domestic media took an ambiguous position with respect to the armed ending of the constitutional conflict between the President of the Russian Federation and the Supreme Council of the Russian Federation, some journalists directly participated in the conflict, and "on different sides of the barricades." The authors tried to reflect their own opinion on the current historical moment by virtue of their understanding, preferences and sympathies.

It was difficult for Russian newspapers to fulfill the role of a dispassionate citizen informant on the current political situation. Therefore, the power structures resorted to the tried and tested means - censorship and prohibitions. And a number of opposition newspapers were not released during the acute phase of the conflict. This period could be described as an "information war", a war for the minds, which ultimately predetermined the historic choice of a new Russia, securing the victory of the President BN. Yeltsin' $s$ supporters and made it clear that the formation of a new civil society in Russia was not going to be easy and would take many years.

\section{REFERENCES}

[1] M. Delyagin, 20 Years of the Execution of Russian Democracy: The Significance and Lessons of the Crisis of 1993 // Free thought. 2013 No. 5 (1641). pp. 5-6.

[2] Boris Yeltsin, Notes of the President. M. AST, 2006. 447 p.

[3] Yeltsin-Khasbulatov: Unity, Compromise, Struggle / Comp: LN Dobrokhotov (head), V.N. Kolodezhny, A.I. Kozhokina, G.V. Lobantsova; Ed. M. K. Gorshkov, V. V. Zhuravlev. - Moscow: TERRA, 1994. $616 \mathrm{p}$

[4] Yeltsin Center (Boris Yeltsin's Presidential Center) // http://www.yeltsincenter.ru/books/aboutyeltsin

[5] A. Korzhakov, Boris Yeltsin: From Dawn to Dusk. M. Publishing House Interbuk. 1997. $480 \mathrm{p}$

[6] V. Kostikov, Relations with the President. Notes of the Press Secretary. M. VAGRIUS, 1997. 351 p.

[7] International Foundation for Socio-Economic and Political Studies (Gorbachev Foundation) - http://www.gorby.ru

[8] L. Y. Sukhanov, How Yeltsin Became President. Notes of the First Mate / Lev Sukhanov. - Exmo: Algorithm, 2011. - 224 c- Source: http://www.yeltsincenter.ru/books/kak-eltsin-stal-prezidentomzapiski-pervogo-pomoshchnika (circulation date - 12/02/2018).

[9] R.I. Khasbulatov, Great Russian Tragedy. - MP Palea - Al-Kods, 1994. // http://1993.sovnarkom.ru/KNIGI/HASBULAT/hasb2-16.htm (circulation date - 12/02/2018)

[10] E.A. Markov, The Role of Mass Media in the Conflict between the President and the Supreme Council of Russia (1993) // Bulletin of the Volga Academy of Civil Service, 2011. No. 1, p. 81.

[11] V. Yakov, Parliamentarians Celebrate the Victory, Which Only They Know About” // Izvestia Moscow Inews Ltd., No. 188 (24043) 1993 , pp. 1,3 .

[12] A. Kolesnikov, D. Pushkar, On the Situation in the White House on the Eve of the "Two-Day War "// Moscow News, Moscow Vremya Publishing House No. 40 (686) 1993, pp. 2, 3.

[13] Otto Latsis, The Reaction Started War against Russia. Russia will Crush the War and Reaction // Izvestia, Moscow Inews Ltd., No. 189 (24044) 1993, pp. 1-2, 4.

[14] A. Yakovlev, M. Ulyanov, B. Fedorov, Y. Baturin, S. Stankov, You Can Not Rock the Public Boat // Rossiyskaya Gazeta, Moscow FGBU Editorial Office of the Russian Newspaper No. 186 (802) 1993, pp. 23.

[15] Writers Demand the Government to Take Decisive Action // Izvestia, Moscow Inews Ltd No. 189 (24044) 1993, p. 3.

[16] A. Yakovlev, M. Ulyanov, B. Fedorov, Yu. Baturin, S. Stankov, You Can Not Rock the Public Boat, p. 1.

[17] V. Yakov, Troops in the White House Fire on the Move // Izvestia, Moscow Inews Ltd, No. 190 (24045) 1993; V. Terekhov, Near Rutskiy and Khasbulatov during the storming of the White House // Izvestia, Moscow Inews Ltd., No. 190 (24045) 1993; I. Andreev, The Moscow Police Turns Out to act flawlessly // Izvestia, Moscow Inews Ltd., No. 191 (24046) 1993, pp. 1-3.

[18] Do Not Justify Armed Violence // Rossiyskaya Gazeta, Moscow Editorial Board of the Russian Newspaper, No. 186 (802) 1993, p. 3.

[19] October 4 is Not the Day of victory. This is the Day of our Tragedy// Izvestia, Moscow Inews Ltd., No. 190 (24045) 1993, p. 1.

[20] A. Prokhanov, The Shadow on the Day // Pravda, Moscow publishing house Pravda, No. 191 (27145), 1993.

[21] A. Prokhanov, The Day is Closed // Soviet Russia, Moscow Publishing House Sovetskaya Rossiya No. 117 (10980).

[22] O. Veldin, V. Gorshenin, V. Kharlamov, The Feast of Faith, Hope, Love in the Homeland // Pravda, Moscow Pravda Publishing House, No. 190 (27144) 1993; V. Kravtsov, In the Ring of Democracy // Pravda, Moscow Pravda Publishing house, No. 191 (27145) 1993; G. 
Ovcharenko, OMON, Aren't you Ashamed? // Pravda, Moscow Pravda Publishing house, No. 191 (27145) 1993, pp. 1-2.

[23] S. Turchenko, The Night of Black Batons // Soviet Russia, Moscow Publishing House Sovetskaya Rossiya, No. 116 (10979); Reporting from Moscow Streets // Soviet Russia, Moscow Publishing House Soviet Russia No. 117 (10980), p. 1.

[24] F. Goncharuk, Armed and Very Dangerous // Pravda, Moscow Pravda Publishing House, No. 191 (27145), 1993, p. 2.

[25] V. Kravtsov, V. Kharlamov, The Night Is Longer than the Day // Pravda, Moscow Pravda Publishing House, No. 191 (27145), 1993, pp. 1-2.

[26] "Who Tramples Freedom of Speech" // Soviet Russia, Moscow Publishing House Sovetskaya Rossiya, No. 117 (10980), p. 1.

[27] "Over Funeral Candles" // Pravda, Moscow Pravda Publishing House, No. 191 (27145), 1993. pp. 1-2. 